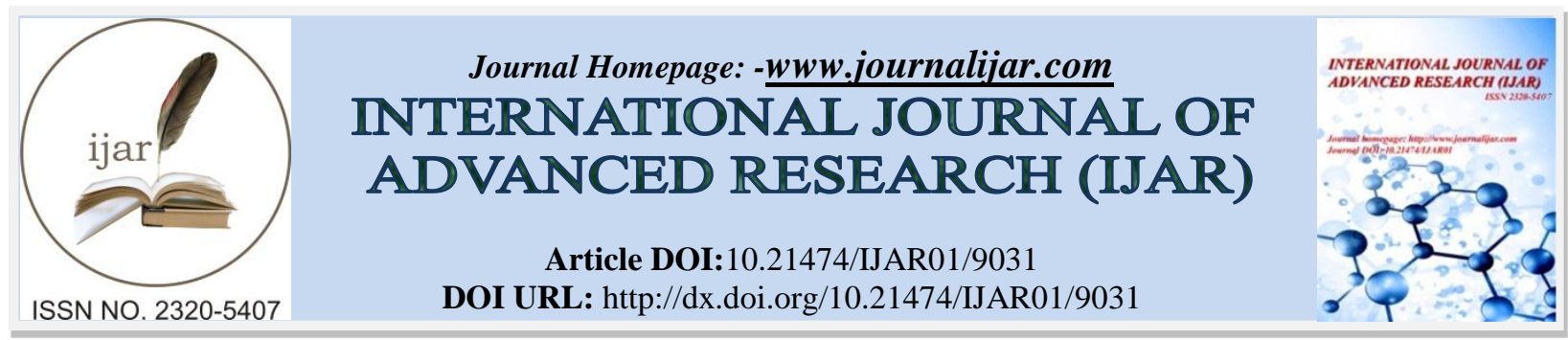

RESEARCH ARTICLE

\title{
ASSESSMENT OF KNOWLEDGE AND ATTITUDE ON PALLIATIVE CARE AMONG NURSING OFFICERS AT TERTIARY CARE CENTRE OF SOUTH INDIA.
}

\author{
Mrs. Arul Nisha S.Tutor, Sattish N, Shanmugapriyan and Surendran S. \\ CON, Jipmer, Puducherry-6.
}

\section{Manuscript Info}

\section{Manuscript History}

Received: 08 March 2019

Final Accepted: 10 April 2019

Published: May 2019

\section{Abstract}

It is estimated in India the total number of people who need palliative care is likely to be 5.4 million people a year. The nurse is a key member of health team who typically has the greatest contact with the patient. This prolonged contact gives the nurse a unique opportunity to know the patient and the caregivers, to assess in depth what is happening and what is of importance to the patient, and to assist the patient to cope with the effects of advancing disease.

Aim: The present study aims to identify the level of knowledge and Attitude on Palliative care among Nursing officers at Tertiary care centre.

Methods: The cross -sectional descriptive study conducted in 171 samples. The subjects were selected based on convenient sampling technique.

Result:Out of 171 Nursing officers majority of the nursing personnel $64.3 \%$ had moderately adequate knowledge and $34.5 \%$ had adequate knowledge and $0.12 \%$ had inadequate knowledge. Majority of the nursing officers $97.07 \%$ had favorable attitude and only $2.9 \%$ had unfavorable attitude . Correlation of level of knowledge and attitude among the staff nurses indicates a positive correlation and shows the results, $\mathrm{p}$-value (0.0002) are highly significant.

Conclusion: This study revealed that the majority of the nurses have moderately adequate knowledge and favorable attitude on palliative care.

Copy Right, IJAR, 2019,. All rights reserved.

\section{Introduction:-}

Death is an inevitable phenomenon that affects every human being. Nurses are present at both the beginning and the end of life, and play a key role in caring for dying patients. That role is seen as one of the most stressful facets of nursing (Hopkinson, Hallett, and Luker, 2005). ${ }^{1}$

Palliative care is a term derived from Latin word Palliare, "to cloak". Palliative care is an approach that improves the quality of life of patients and their families facing the problem associated with life threatening illness, through prevention and relief of suffering by means of early identification, assessment and treatment of pain, and other problems- physical, psychological, and spiritual. ${ }^{2}$

Corresponding Author:-Mrs. Arul Nisha S.Tutor.

Address:-CON, Jipmer, Puducherry-6. 
It is estimated in India the total number of people who need palliative care is likely to be 5.4 million people a year. Palliative care is the active total care of patient in advanced and incurable stages of cancer. More than $70 \%$ of all cancer patients in India require palliative care for relief of pain, other symptoms and psychosocial distress. The need for education and training in palliative care has been emphasized by the World Health Organization. ${ }^{5}$

The limited availability of palliative care services structures within a hospital or outside make it difficult for a patients and their families to go through the terminal phase of disease and dying. This is further compounded by the lack of an adequate number of health professionals trained to deliver the palliative and end of life care. ${ }^{2}$

By 2020, the World Health Organization (WHO) estimates that non-communicable diseases (NCDs) will be as prevalent as communicable diseases, which have been the main cause of high morbidity and mortality among the world population. It is a major undertaking for health systems worldwide to deliver appropriate palliative care. Many countries have experienced dramatic improvements in population life expectancy. The proportion of elderly people, and particularly those over 80 , has increased significantly in recent decades. As populations age, people die in greater numbers after long illnesses from heart disease, cerebrovascular disease including stroke, chronic respiratory disease and respiratory infections, and cancer. Palliative care is concerned both with patients and their families and with the enhancement of quality of life from an early stage in a life-threatening illness. ${ }^{1}$

To provide quality care at the end of life or for chronically sick patients, Nurses must have good knowledge, attitude and practice about palliative care.

\section{Materials \& Method:-}

The primary objective of the study is to assess the knowledge and attitude on palliative care among Nursing officers and the secondary objective of the study is to identify the relation between knowledge and attitude among nursing officers. The study was conducted at Tertiary care centre of South India under ministry of health and family welfare and an institution of national importance. A cross sectional descriptive research design was used to assess the knowledge and attitude regarding palliative care among nursing officers at Tertiary care centre. The study included 171 Nursing officers. The convenience sampling technique was used to select the study sample. The sample size is estimated with an expected population of patients with good knowledge conducted by Thomas $\mathrm{N}$ et al 2015 . regarding the palliative care as $0.50(50 \%)$ and the sample size is estimated at $5 \%$ level and $15 \%$ relative precision. The instrument consists of three parts. Demographic variable consist of age, gender, level of education, work experience, experience in caring terminally ill patients. The assessment of knowledge by using knowledge questions which came from the Palliative Care Quiz for Nursing (PCQN) using questions with yes, no, or don't know answers. The attitude assessment done through the original Fromolet Attitude Toward Care of the Dying (FATCOD) questionnaire which consists of 23 items. The tool has a 5 point Likert scale. This was used to represent people's attitudes to a topic scored on 5 point scale, i.e. 1 (Strongly Disagree), 2 (Disagree), 3 (Uncertain), 4 (Agree) to 5 (Strongly Agree). In Score interpretation of knowledge The Palliative Care Quiz for Nursing questionnaire has 14 questionnaires and each question has 3 options from which the nurses has to choose one best option by ticking against it. A score value of " 2 "were allotted for each "yes" response given, value of " 1 " were allotted for each "no" response and the "don't know" answers were given "0"score. For assessing attitude the FATCOD scale has 23 questionnaires and each question has 5 options from which the nurse has to choose one best option by ticking against it. A score value of " 1 " were given for "Strongly Disagree", "2" were given for "Disagree", "3" were given for "Uncertain", "4" were given for "Agree" and "5" were given "Strongly Agree". Ethical Committee permission was obtained from the Institutional Review Board. Written permission obtained to use this scale from the authors..A written informed consent was taken from all participants.

Table 1:-Level of the knowledge regarding palliative care among Nursing officers

\begin{tabular}{|l|l|l|l|l|}
\hline $\begin{array}{l}\text { LEVEL OF } \\
\text { KNOWLEDGE }\end{array}$ & FREQUENCY (N) & PRECENTAGE (\%) & MEAN & $\begin{array}{l}\text { STANDARD } \\
\text { DEVIATION }\end{array}$ \\
\hline $\begin{array}{l}\text { Adequate } \\
\text { knowledge } \\
(\geq 30 \text { score } \geq 75 \%)\end{array}$ & 59 & 34.5 & 27.9 & 3.16 \\
\cline { 1 - 4 } & 110 & 64.3 & & \\
$\begin{array}{l}\text { adequate } \\
\text { knowledge (29-21 }\end{array}$ & & & \\
\hline
\end{tabular}




\begin{tabular}{|l|l|l|l|l|}
\hline score/ 74-51\%) & & & \\
\hline $\begin{array}{l}\text { Inadequate } \\
\text { knowledge } \\
(\leq 20 \text { score/ } \leq 50 \%)\end{array}$ & 2 & 0.12 & & \\
\hline
\end{tabular}

Table 2:-Level of the attitude regarding palliative care among Nursing officers

\begin{tabular}{|l|l|l|l|l|}
\hline $\begin{array}{l}\text { LEVEL OF } \\
\text { ATTITUDE }\end{array}$ & FREQUENCY (N) & PRECENTAGE (\%) & MEAN & $\begin{array}{l}\text { STANDARD } \\
\text { DEVIATION }\end{array}$ \\
\hline $\begin{array}{l}\text { Favorable attitude } \\
\begin{array}{l}>60 \text { score- more } \\
\text { than 50\%) }\end{array}\end{array}$ & 166 & 97.07 & 82.3 & 9.5 \\
\cline { 1 - 2 } $\begin{array}{l}\text { Unfavorable } \\
\text { attitude }(<60 \\
\text { score-less than } \\
50 \%)\end{array}$ & 5 & 2.9 & & \\
\hline
\end{tabular}

Table 3:-Correlation between the knowledge and attitude regarding palliative care among Nursing officers

\begin{tabular}{|l|l|l|l|l|}
\hline \multirow{2}{*}{ VARIABLES } & \multicolumn{2}{|l|}{ STAFF NURSES } & \multirow{2}{*}{ r-VALUE } & \multirow{2}{*}{ p-VALUE } \\
\cline { 2 - 3 } & MEAN & S.D & & \\
\hline LEVEL OF KNOWLEDGE & 27.9 & 3.16 & \multirow{2}{*}{0.28} & $0.0002^{* *}$ \\
\hline LEVEL OF ATTITUDE & 82.3 & 9.5 & \\
\hline
\end{tabular}

$* *$-p $<0.05$, highly significant

\section{Results:-}

Out of 171 Nursing officers majority of the nursing personnel had $110(64.3 \%)$ had moderately adequate knowledge and $59(34.5 \%)$ had adequate knowledge and inadequate knowledge $2(0.12 \%)$ (Table:1). Majority of the nursing personnel had $166(97.07 \%)$ had favorable attitude and 5 (2.9\%) had unfavorable attitude (Table:2). The mean of the level of knowledge is 27.9 with standard deviation of 3.16. The mean of the level of attitude is 82.3 with standard deviation of 9.5. Correlation of level of knowledge and perception among the staff nurses indicates a positive correlation and shows the results, p-value (0.0002) are highly significant (Table:3). Educational qualification shows that 7(4.1\%) belongs to the diploma in nursing, $133(77.8 \%)$ belongs to B.Sc. nursing and 31(18.1\%) belongs to the M.Sc. nursing and others. No one has attended any special training regarding Palliative care.

\section{Discussion:-}

The study was intended to identify the level of knowledge and attitude on palliative care among Nursing officers at Tertiary care centre of South India.. Among 171 nursing officers majority of the staff nurses had moderately adequate knowledge $(64.3 \%)$, (34.5\%) of the nurses had adequate knowledge, and $(0.12 \%)$ of the nurses had inadequate knowledge. The findings of the present study was supported by Thomas $\mathrm{N} \mathrm{et} \mathrm{al}{ }^{10}$. Majority of the nursing personnel had $166(97.07 \%)$ had favorable attitude and $5(2.9 \%)$ had unfavorable attitude. The finding of the study was supported by Thomas $\mathrm{N}$ et $\mathrm{al}^{10}$. The mean value is 82.3 and standard deviation is 9.5 . The correlation between the knowledge and attitude regarding palliative care among staff nurses indicated a positive correlation and showed the results were highly significant with a p-value of (0.0002).

\section{Conclusion:-}

Knowledge on palliative care is essential for nurses who encounter patients with terminal illness like cancer. As cancer is the leading cause of death, nurses will have challenges in many ways, if their preparation for this situation is not adequate. The researcher inquired about the knowledge and practice in order to determine how much nurses really know and practice palliative care. This study revealed that the majority of nurses have moderately adequate knowledge and favorable attitude on palliative care.

\section{Bibliography:-}

1. Ayed A, Sayej S, Harazneh L, Fashafsheh I, EqtaitF.The Nurses' Knowledge and Attitudes towards the Palliative care.Journal of education and Practice .2015; 6: 91.

2. World Health Organization (WHO): WHO definition of palliative care. 2006. Available from: http://www.who.int/cancer/palliative/definition/en/ 
3. Kar S S, Subitha L, Iswarya S. Palliative care in India: Situation assessment and future scope. Indian J Cancer 2015; 52: 99-101.

4. Lavy, R.C., 2005. Palliative care in children advanced HIV/AIDS. Palliat Med., (17): 51-2.

5. Hotez, P.J. and A.S. Daar, 2008. The CNCDs and the professionals. Palliat Med. 23: 754-66. NTDs: blurring the lines dividing noncommunicable and communicable chronic disease. PloSNegl. Trop Dis., (2): 312.

6. Gopal KS, Archana PS.Awareness, Knowledge and Attitude about Palliative Care, in General, Population and Health Care Professionals in Tertiary Care Hospital. International Journal of Scientific Study.2016; 3: 31-5.

7. Unroe KT, Cagle JG, Lane KA, Callahan CM, Miller SC.Nursing Home Staff Palliative Care Knowledge and Practices: Results of a Large Survey of Frontline Workers.J Pain Symptom Manage.2015; 50: 622-9.

8. Ayed A, Sayej S, Harazneh L, Fashafsheh I, EqtaitF.The Nurses' Knowledge and Attitudes towards the Palliative Care.Journal of Education and Practice.2015; 6: 91.

9. Thomas N, Nixen N, Ramshida T.A, Gireesh. A descriptive study to assess the knowledge and attitude of staff nurses regarding palliative care in selected hospital, Mangaluru. American International Journal of Research in Humanities, Arts and Social Sciences. 2015; 13: 6-9.

10. Das AG, Haseena T, Venjaramoodu. Knowledge and Attitude of Staff Nurses Regarding Palliative Care. . International Journal of Science and Research (IJSR). 2015; 4: 1790-4. 